\begin{tabular}{|ll|}
\hline $\begin{array}{l}\text { Social Work/Maatskaplike Werk Vol } 57 \text { No } 1 \text {; Issue } 1 \\
\text { http://socialwork.journals.ac.za/pub }\end{array}$ & doi:http://dx.doi.org/10.15270/52-2-903 \\
\hline
\end{tabular}

INFORMATION AND COMMUNICATIONS TECHNOLOGY (ICT) ACCESS FOR PRACTICALS AMONG SOCIAL WORK STUDENTS IN AN OPEN DISTANCE LEARNING UNIVERSITY

Boitumelo Joyce Mohapi, Caroline Agboola, Simon Kang'ethe

Boitumelo Joyce Mohapi, Caroline Agboola, Simon Kang'ethe

This study utilised a non-experimental, quantitative research design to describe the ICT experiences of fourth-year Social Work students of the University of South Africa. Non-probability purposive sampling was used to select a sample of 317 students for the study. A questionnaire was used as a data-collection instrument and the data collected were analysed using SPSS. The study's findings indicated that the majority of the students (83.5\%) have access to computers, but some of them could not access the internet because of inadequate knowledge of computer usage, lack of financial resources to buy a laptop, and the cost of commuting to a computer centre.

Dr Boitumelo Joyce Mohapi, Department of Social Work, University of South Africa (UNISA), Pretoria, South Africa.

Dr Caroline Agboola, Department of Sociology, University of South Africa (UNISA), Pretoria, South Africa.

Prof. Simon Kang'ethe, Department of Social Work and Social Development, University of Fort Hare, Alice, South Africa.

Boitumelo Joyce Mohapi, ORCID iD: 0000-0002-0497-1192

Caroline Agboola, ORCID iD: 0000-0002-8862-7566

Simon Kang'ethe, ORCID iD: 0000-0001-9150-0235

Boitumelo Joyce Mohapi: Mohapbj@unisa.ac.za

Caroline Agboola: agboolacaroline@gmail.com

Simon Kang'ethe: SKangethe@ufh.ac.za

Keywords: access for practicals, information and communications technology (ICT), open distance learning, practical work assessment, social work, social work students 


\title{
INFORMATION AND COMMUNICATIONS TECHNOLOGY (ICT) ACCESS FOR PRACTICALS AMONG SOCIAL WORK STUDENTS IN AN OPEN DISTANCE LEARNING UNIVERSITY
}

\author{
Boitumelo Joyce Mohapi, Caroline Agboola, Simon Kang'ethe
}

Dr Boitumelo Joyce Mohapi, Department of Social Work, University of South Africa (UNISA), Pretoria, South Africa.

Dr Caroline Agboola, Department of Sociology, University of South Africa (UNISA), Pretoria, South Africa.

Professor Simon Kang'ethe, Department of Social Work and Social Development, University of Fort Hare, Alice, South Africa.

Keywords: access for practicals, information and communications technology (ICT), open distance learning, practical work assessment, social work, social work students

\section{INTRODUCTION}

The University of South Africa (Unisa) is an open and distance learning (ODL) institution with the largest ODL student population in Africa (The leading ODL University, 2019). It uses various forms of technology, such as the MyUnisa platform (UNISA, [sa]a) to communicate with students about the payment of tuition fees, research and community engagement functions (Ahmed \& Palermo, 2010).

As noted by Arinto (2016:162), the "rapid advances in information and communications technology in the digital age have brought about significant changes in the practice of distance education (DE) worldwide". This is demonstrated by a move from printed learning materials to virtual learning platforms (Courtney \& Wilhoite-Mathews, 2015). Over time, the medium of learning in DE has evolved from a postal service to educational radio and television programmes, cell phones and the internet (Kashora, Van Der Poll and Van Der Poll, 2012). This evolution has enhanced the efficiency and effectiveness of learning platforms (Lee, 2017). It is this realisation of the impact of ICT that motivated the Department of Social Work at Unisa to transform its activities so that they could align with the technologically advancing activities of Unisa as an ODL university. The transformation also served as an added motivation to attempt to embrace the principles and ethos of the fourth industrial revolution, with ICT as its engine (Penprase, 2018). It is widely recognised that Universities bereft of technological advancement need to upscale and upgrade their infrastructure to be fourth industrial revolution-friendly, if they want to be competitive with the likes of those of the Western world and of emerging countries such as Singapore and South Korea (Gleason, 2018; Jeong, 2018). Perhaps the importance of access to ICT and its implementation cannot be over-emphasised in this perilous epoch of COVID-19, where all the institutions have been forced to resort to remote learning. This is because of the need to achieve zero tolerance of physical contact and to maintain the ethos of social distancing (Commonwealth of Learning, [sa]; HMC architects, [sa]).

Historically, the assessment of case and group work practical modules at Unisa has been conducted by bona fide practical-oriented lecturers of these modules (Mohapi, 2010). This has entailed having the students submit a portfolio of evidence, which accounts for $50 \%$ of the final mark; and an oral assessment, which made up 50\% of the final mark. This process has become both cumbersome and daunting, given the growing number of students at UNISA (UNISA, [sa]c). For example, in 2011 the rising student numbers at UNISA informed a decision that required all lecturers to become involved in the final assessments of case work and group work practicals. This entailed developing a detailed assessment guide for case and group work, and a marking guide for the portfolios. But this was not feasible because of fatigue and the heavy load work involved; it was also a very tiring exercise. This gave an impetus and a motivation to explore the development of alternative methods of assessment, with access of ICT 
becoming an option. With the access to ICT infrastructural tools such as computers, iPads and tablets, students would be able to submit their portfolios or record their practical work and send audio or video files with ease. This approach was also emphasised by the Council on Higher Education (2014), which noted that various technologies could be used in different ways to support any combination of teaching and learning, and that universities had to keep these options open. Ideally, the access to different technologies would reduce time lost in the manual assessment and is also an effective and efficient method of managing the learning process.

The use of ICT in institutions of higher learning is a strong litmus test of the country embracing the tenets of the fourth industrial revolution (Xing \& Marwala, 2017). To this end, Coulby, Hennessy, Davies \& Fuller (2011) argue that there is a need for a cultural and cognitive mind shift to embrace the use and access of technology in mobile learning in all higher education institutions. Similarly, learning with the aid of computers is essential for students, particularly those in ODL institutions, because they study remotely (UNISA, 2008) without physically coming to the campus for support in contrast to the use of traditional face-to-face modes of learning. The process offers some flexibility, is motivative, effective and efficient (Iqbal \& Ahmad, 2010; Sullivan, 2009). In the health and social care environment, which includes social work, there is a need for a major re-thinking about the continued use of traditional ways of learning and teaching, and to embrace the use of technology in the learning environment by staff, students and clients. This is because a large part of the curriculum includes work-based learning, where academic contractors are employed to supervise students in various workplace settings (Mohapi, 2010). It is crucial then that the department and staff jointly decide to discard their analogue thinking and become digital (Sullivan, 2009). This view is also highlighted by the Council for Higher Education (2014), which maintains that providers of distance education are harnessing technology to improve their processes of teaching and learning. This is a litmus test for achieving effectiveness and efficiency in learning (Sullivan, 2009).

\section{BACKGROUND}

Globally, regionally and locally distance education (DE) has witnessed profound changes over time (Courtney \& Wilhoite-Mathews, 2015). Previously, radio, television, audio tapes and the postal service constituted the medium of teaching of learning in DE (Kashora, Van der Poll \& Van der Poll, 2012). However, DE is increasingly diversifying to include print and electronic media (Chawinga \& Zozie, 2016:5), embracing the concept of 'open' and its associated inclusion of technology. The component of 'open' in ODL suggests that education be made available to everyone, irrespective of their backgrounds (Chawinga \& Zozie, 2016:4). According to The Sage Glossary of the Social and Behavioral Science, distance education is

a mode of education whereby learner $(s)$ and teacher $(s)$ are physically separated from one another and the instructional processes are fulfilled via information and communication technologies. Realistically, distance education alters the conventional patterns of education and provides opportunities of learning whenever and wherever needed (Sullivan, 2009:158).

The infusion of ICT into ODL has impacted practices in ODL. Rogerson-Revell (2015) contend that technologies provide an array of opportunities to teaching and learning in ODL, particularly when facilitating interactive and collaborative learning. But this has faced constraints, stifling the successful implementation of the use of and access to technologies. For example, the high cost of internet access in South Africa remains a challenge for students at ODL universities, particularly those students reside in rural areas (Gillwald, 2017). Evidence abounds that previously disadvantaged communities in South African rural areas face high levels of unemployment, poverty and the concomitant financial difficulties (Swart, 2015). As a result, students in rural areas are not able to afford the needed access to the internet and computers.

Professional practice of health and social care, including social work, constitutes a body of knowledge gathered from practice experiences, with practice-based education as their mode of education (Taylor, 
Dearnley, Laxton, Coates, Treasure-Jones, Campbell \& Hall, 2010). This study discusses the experience of the respondents in accessing ICT to acquire practical work experiences, as stipulated for the social work profession. The access to and use of technology-assisted initiatives in ODL to assess professional competencies in group and case work become imperative in the light of increased Social Work student numbers at Unisa. Heavy teaching workloads (Swart, 2015) and the increase in the number of Social Work students at Unisa make technology, especially in recording and submitting practical work, a useful tool to enhance teaching and learning. This study examines issues around the respondents' use of technology to record and submit their group and case work. The study was guided by the following research question: To what extent do fourth-level Social Work students have access to information and communication technology (ICT) infrastructure for their case and group work?

\section{PROBLEM STATEMENT}

Assessment is an integral part of teaching and learning. The University of South Africa (Unisa) uses a range of technologies to facilitate learning, teaching and assessment. These include a learner management system, known as MyUnisa, which supports online teaching, learning and assessment (UNISA, [sa]a). Unisa also makes use of 'on-screen marking', whereby assessors can mark assignments and do online formative assessments, using a pdf-based on-screen marking software application. Eportfolios are also used in some postgraduate modules for non-venue based summative assessments (Madiope \& Govender, 2015).

The South African reality is that not all communities have equal access to resources, including technology (Letseka \& Pitsoe, 2013). Some communities do not have access to electricity, which is also necessary for accessing technological resources. This is confirmed by Bozalek \& Ng'amibi (2015), who posit that access to digital devices for higher education students is increasingly differentiated, because there is a group of students who go to university in the first year with inadequate access to ICT and a lack of basic computer literacy. This might be because these students have little or no computer and internet access at home. Since Unisa has made certain technologies available to enhance teaching, learning and assessment, it is vital to explore whether all students have access to such technologies to enhance their learning and assessment.

\section{THEORETICAL FRAMEWORK}

This study employed a constructivist learning theory. This constructivist theory is rooted in education, psychology, sociology and philosophy and can be traced back to ancient philosophers such as Plato, Aristotle and Socrates, and more recently in the works of Dewer, Vygotsky, Piaget, Von Glasersfeld and Dougimas (Sakarneh \& Al-Swelmyeen, 2020; Liu and Chen, 2010). The underlying principle of constructivism is that students actively construct their own knowledge, on the basis that they should not be passive receivers of information (Jonassen, 1991; Padirayon, Pagudpud \& Cruz, 2019; Qiu, 2019). Applying constructivism to this study, it can be argued that if students have access to the necessary technology to enhance their learning, they can be active participants in knowledge building. This can be done either individually (cognitive constructivism - see Olusegun, 2015) or collaboratively with other students (social constructivism - see Liu \& Chen, 2010). Thus, when students do their practical work, they can use technology to work individually or in teams, but the outcome is their involvement in constructing knowledge (Jonassen, 1991).

\section{RESEARCH METHODS AND STUDY SETTINGS Purpose of the study}

The purpose of the study was to determine the level of access and use of technology for assessing the practical work of fourth-level Social Work students. This study was informed by an informal communityengagement initiative undertaken by the principal researcher to ascertain the accessibility of ICT services for Social Work students for practical work purposes. 


\section{Research design}

This study used a non-experimental quantitative research design (Reio, 2016) to describe and explore as well as explain the ICT experiences of fourth-year Social Work students. Non-probability purposive sampling (Etikan, Musa \& Alkassim, 2016; Landreneau, (n.d); Frankfort-Nachmias \& Nachmias, 2000) was used to select the sample for this study.

\section{Research instrument}

Data were collected through the use of questionnaires (Krosnik, 2018), which included follow-up questions to obtain more information about responses to previous questions (Delport and Roestenburg, 2011). The questionnaires were self-administered (Dinisman, 2016) as the respondents completed them on their own. A 79.25\% response rate was achieved. Although what constitutes an acceptable response rate is contentious, Frankfort-Nachmias \& Nachmias (2000) consider a response rate of $75 \%$ and above as acceptably high. Frankfort-Nachmias \& Nachmias (2000) note that with the use of non-probability sampling in studies, such as this one, the probability of each member of the population being included in the study cannot be assured. While this study cannot be said to be a fully representative, some degree of representativeness can be found in the non-probability purposive sampling (Etikan \& Bala, 2017; Frankfort-Nachmias \& Nachmias, 2000) that was used, more so because of the high response rate that was achieved.

\section{Sample selection criteria, data collection and procedure}

The criteria for inclusion in the study was that a student should be registered for both case work and group work practical work modules in Social Work. Non-probability purposive sampling (Etikan, Musa \& Alkassim, 2016; Etikan \& Bala, 2017) was used for this study. Out of a population of 400 fourth-year Social Work students, 317 were sampled. The study was a one-off exercise. Social Work lecturers who were conducting the summative assessment of Social Work students in the various regions distributed the questionnaires to the students, which they completed and submitted to the lecturer.

\section{Data analysis}

The data collected by means of the questionnaires were analysed using Statistical Package for the Social Sciences (SPSS) versions 19 and 20 (Creswell, 2009; George \& Mallery, 2003). This statistical programme was used to analyse, describe and summarise the findings through coding, which entailed putting the similar findings into one category to constitute themes.

\section{Ethical requirements}

Even though the study did not pose any risk to participants, ethical principles were observed in accordance with research that is conducted on human participants. Hence, the following ethical issues were taken into account in conducting this research.

\section{Informed consent and voluntary participation}

The respondents were given a letter explaining the purpose of the research, and they were requested to sign an informed consent form before data collection commenced. Respect for the right of selfdetermination (Frankfort-Nachmias \& Nachmias, 2000) was maintained in this study by seeking the voluntary participation of the respondents.

\section{Privacy, anonymity and confidentiality}

In order to protect the privacy of the respondents and ensure their anonymity and the confidentiality of the information (Frankfort-Nachmias \& Nachmias, 2000; Gerring, 2012), the questionnaire did not require their names or any identifying details.

\section{Deception of subjects}

Deception constitutes an infringement of the rights of research participants (Tai, 2012; FrankfortNachmias \& Nachmias, 2000). The deception of subjects occurs when a researcher intentionally misleads subjects by way of written or verbal instructions, the actions of other people or certain aspects of the 
setting (Neumann, 2000). In this study the respondents were not misled or deceived about the nature of the study. The respondents were informed about the purpose and procedures of the study. This was done by means of an informed consent letter which formed part of the questionnaire.

\section{Research domain}

South Africa is divided into nine provinces, but Unisa, as an open and distance learning university, divides the country into six regions, namely Western Cape, Eastern Cape, KwaZulu-Natal, Gauteng, Limpopo and Midlands (UNISA, [sa]b). The Midlands refers to a combination of the provinces of the Northern Cape, Free State and North-West provinces, whereas Limpopo is a combination of Mpumalanga and Limpopo provinces of South Africa (UNISA, [sa]b). This study was conducted in all six Unisa regions, where summative assessments (oral examinations) of fourth-level Social Work practical modules for case work and group work were being conducted.

\section{FINDINGS}

The results of this study are divided into two categories: accessibility to a computer and internet accessibility. The 10 key findings to be discussed are: in terms of computer accessibility, the location of computer access; reasons for the lack of access to computers; the distance travelled to access computers; the cost of travel to access computers; the types of computers used; and knowledge of computer use. In terms of internet accessibility, reasons for not accessing; distance travelled; monthly cost involved; and the type of internet access.

\section{Demographic profile of respondents}

The figures below indicate the gender of the respondents, the region where they are and their disability profile.

Figure 1 indicates that the majority of the respondents (90\%) were female, and $10 \%$ were male.

FIGURE 1

GENDER OF RESPONDENTS

\section{GENDER OF STUDENTS}

SELECTED

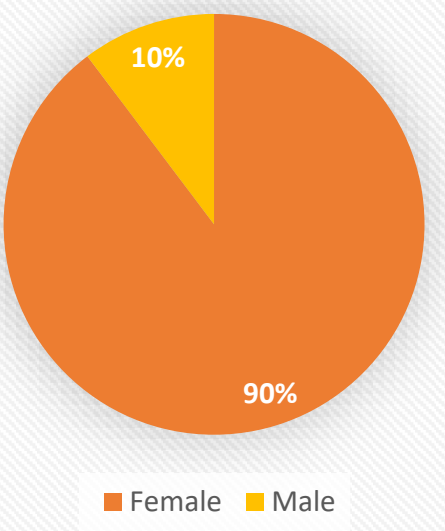


FIGURE 2

UNISA REGIONS WHERE RESPONDENTS RESIDED

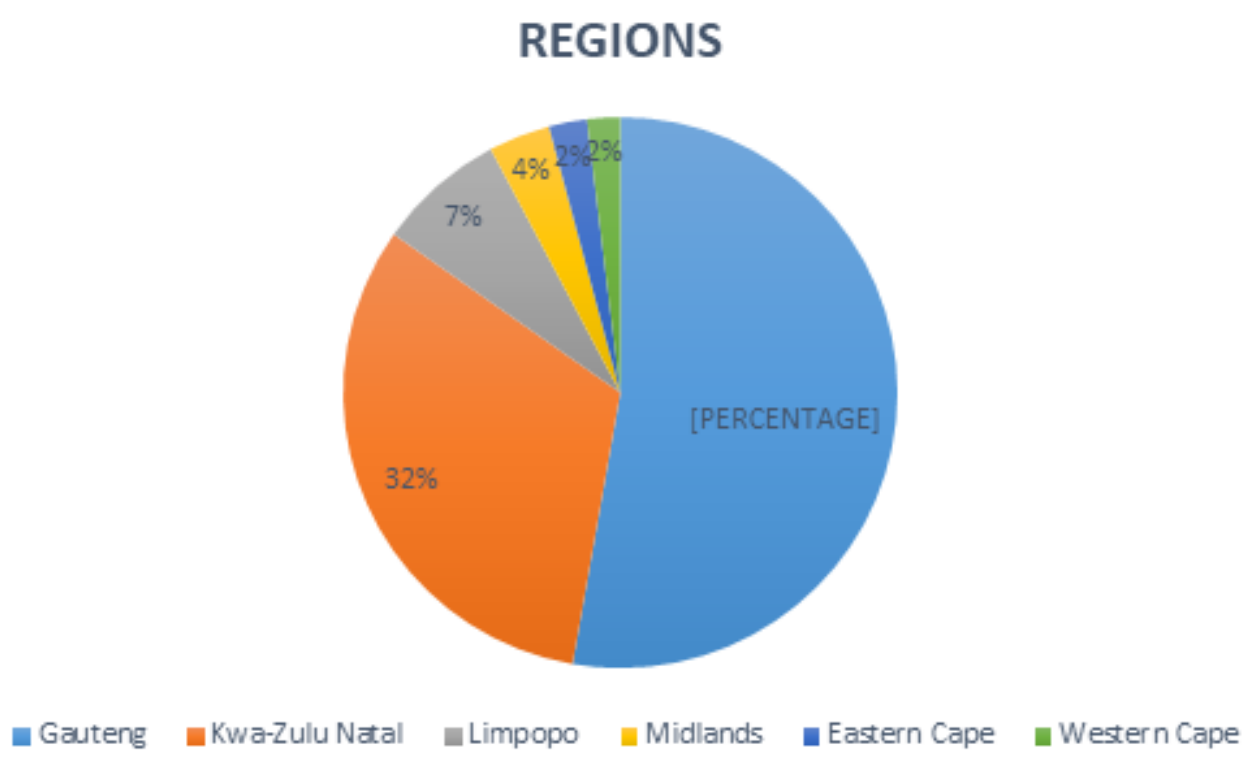

From Figure 2, it is seen that the majority of respondents are from Gauteng region (53\%), followed by KwaZulu-Natal (32\%). Smaller percentages of respondents are from Western Cape, Midlands, Eastern Cape and Limpopo regions.

\section{FIGURE 3}

\section{DISABILITIES}

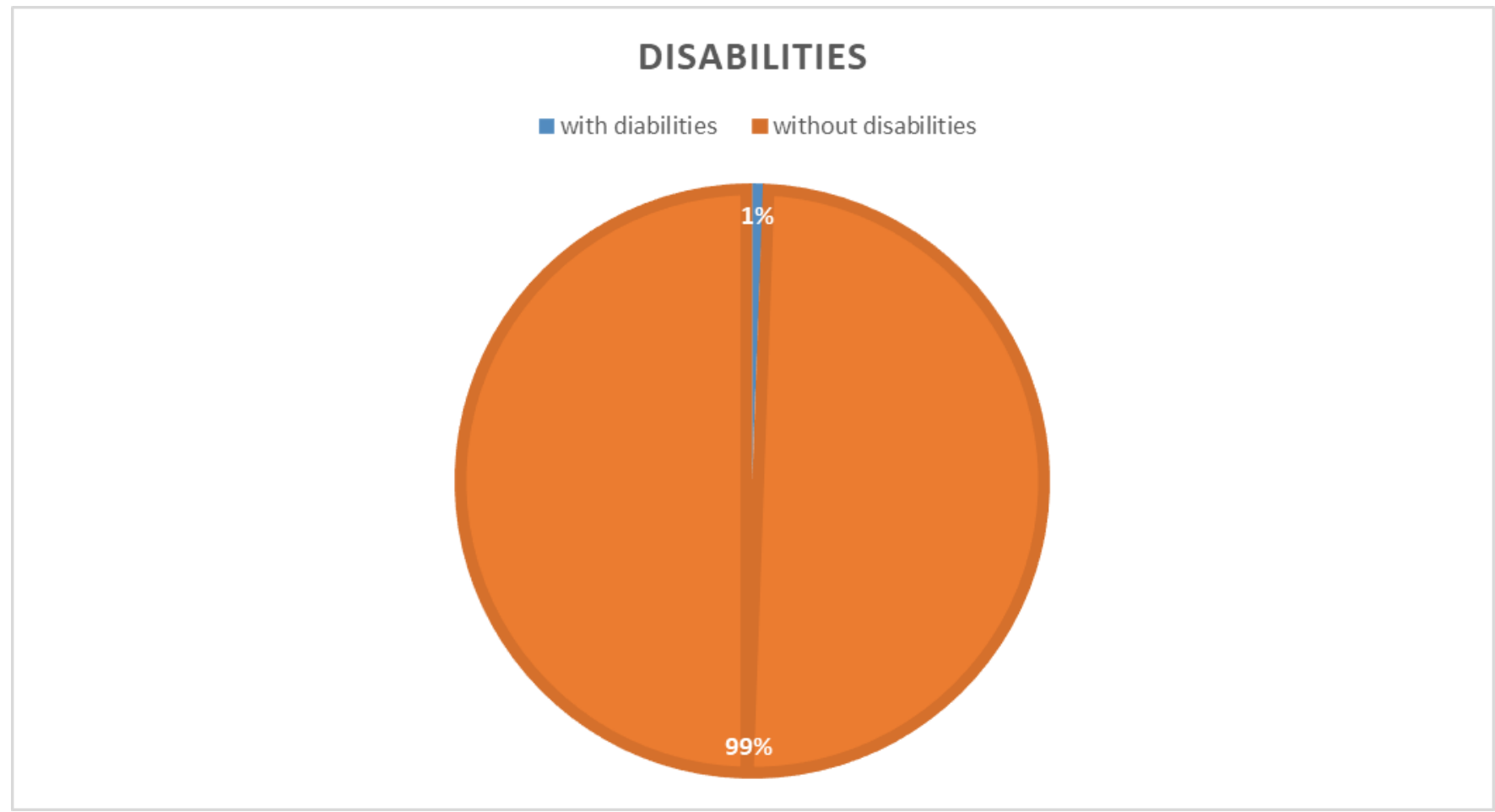

According to Figure 3, the majority of students (99\%) do not have a disability, and only $1 \%$ have a disability.

\section{Accessibility to computer}

Most respondents have access to computers. About 83.5\% (264 respondents) indicated that they have access to a computer, while $16.5 \%$ do not have access to a computer. Among the respondents who have 
access to computers, 259 indicated where they could access them. The question on the location of computer access allowed multiple responses, as shown in Table 1. The multiple responses account for more than $100 \%$ aggregate in some of the tables.

TABLE 1

LOCATIONS WHERE COMPUTERS ARE MOSTLY ACCESSED

\begin{tabular}{lrrc} 
Location & Frequency & \% & Rank \\
Home & 162 & $62.5 \%$ & 1 \\
Work & 57 & $22.0 \%$ & 2 \\
Unisa computer laboratories & 49 & $18.9 \%$ & 3 \\
Internet café & 40 & $15.4 \%$ & 3 \\
Someone else's home & 23 & $8.9 \%$ & 6 \\
Unisa multipurpose community centres (telecentres) & 5 & $1.9 \%$ & 9 \\
Municipality library & 3 & $1.2 \%$ & 9 \\
\hline
\end{tabular}

Respondents most often access computers at their homes. They also have access to computers at work, Unisa computer laboratories, other people's homes and internet cafés. Very few respondents use Unisa multipurpose community centres (telecentres) and municipal libraries.

Among the 52 respondents who do not have access to computers, 48 (92.3\%) gave reasons, as indicated in Table 2. The question on the lack of computer access allowed the multiple responses, as shown in Table 2 .

TABLE 2

\section{REASONS FOR NOT HAVING ACCESS TO A COMPUTER}

\section{Location}

I cannot afford a personal computer

I cannot afford the travel costs to a facility with a computer

I don't know how to use a computer

The office hours of public facilities (internet café or laboratory) that have computer access are not convenient for me

My smartphone enables me to perform basic word processing and spreadsheet functions

I don't know anyone who has a computer

$\begin{array}{cccc}\text { Frequency } & \% & & \text { Rank } \\ 37 & & 77.1 \% & 1 \\ 7 & & 14.6 \% & 2 \\ 6 & & 12.5 \% & 3\end{array}$

4

$8.3 \%$

4

\begin{tabular}{lll}
4 & $8.3 \%$ & 4 \\
4 & $8.3 \%$ & 4 \\
\hline
\end{tabular}

From Table 2, it can be observed that about $77 \%$ of the respondents who do not have access to a computer indicated that they cannot afford one. Four respondents $(8 \%)$ indicated that they do not know how to use a computer.

For those respondents who could access computers, it came at a financial cost in the form of commuting long distances to and from the computer access points. On average, respondents travelled between 5 and $20 \mathrm{~km}$ from their homes to locations where they could access computers. A distribution of the distance travelled by the respondents is indicated in the bar chart (Figure 4). 
FIGURE 4

\section{PERCENTAGE DISTRIBUTION OF DISTANCE TRAVELLED TO ACCESS COMPUTERS BY RESPONDENTS}

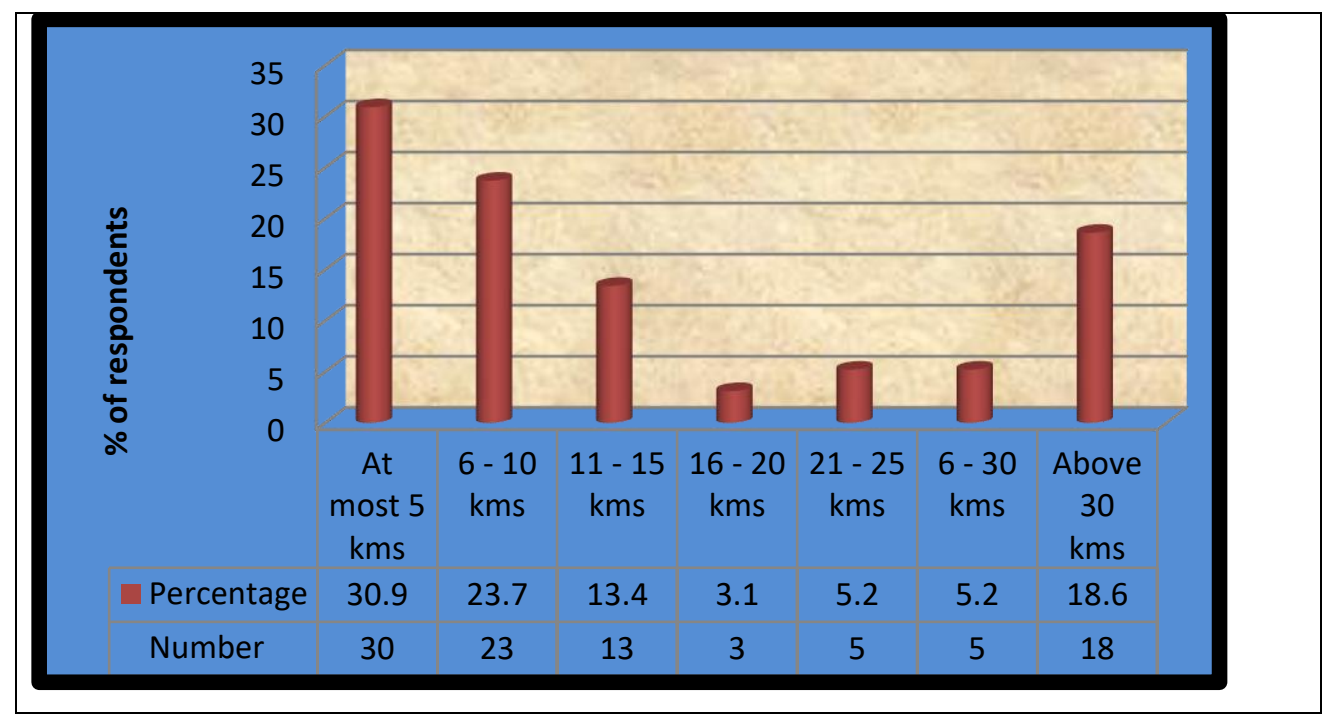

Figure 4 indicates that most respondents were within a radius of $10 \mathrm{~km}$ from the nearest location where they could access computers, with a worrying $18.6 \%$ above $30 \mathrm{~km}$.

With reference to travel costs, the respondents spent an average of R365.94 (approximately 26 US dollars) per month on commuting to the locations of computers. As seen in Figure 5, some respondents spent more than R1 000.00 (approximately 70 US dollars) per month on travel costs to access computers, while most respondents (40.2\%) spent about R200 (approximately 14 US dollars) or less a month.

\section{FIGURE 5}

PERCENTAGE DISTRIBUTION OF MONTHLY COST OF TRAVEL TO ACCESS COMPUTERS BY RESPONDENTS

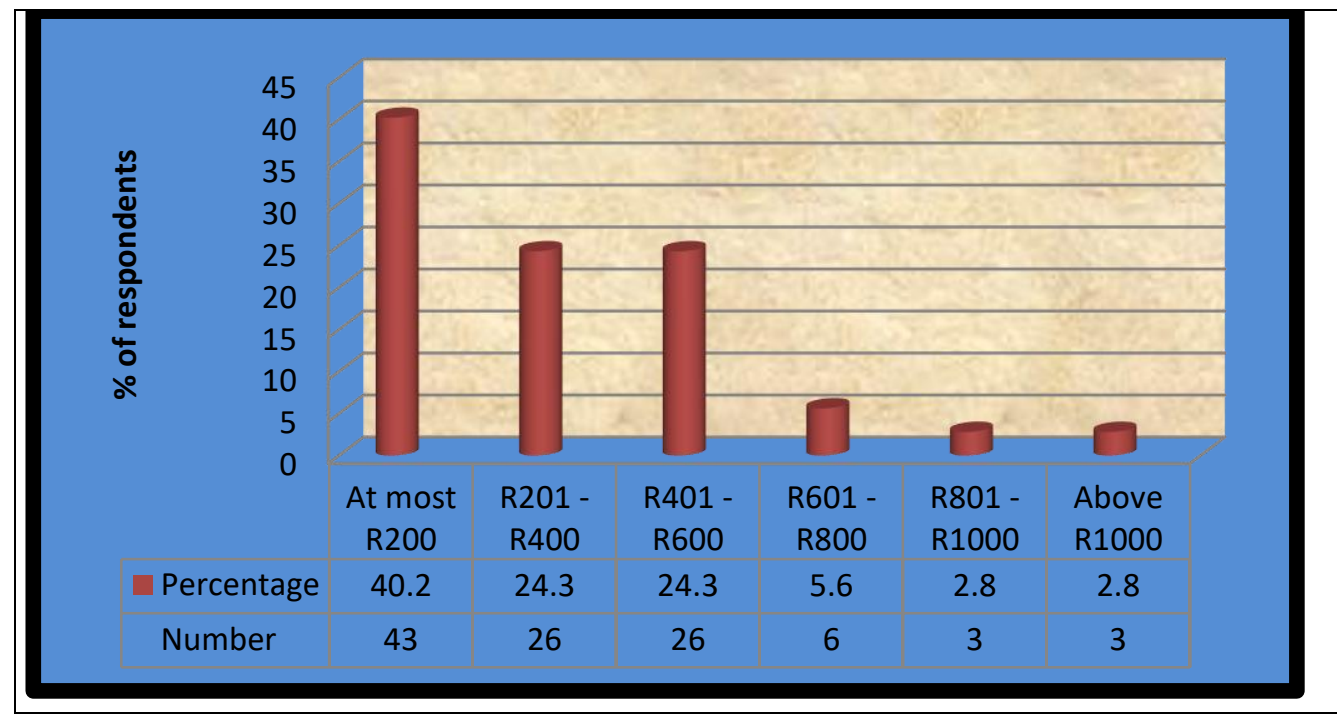

Most respondents prefer laptops. Close to $85 \%$ (143 respondents) indicated that they would like to purchase a laptop, as demonstrated by the data in Table 3 . 
TABLE 3

PREFERRED PERSONAL COMPUTER TYPE

\begin{tabular}{lccc} 
Type & Frequency & \% & Rank \\
Desktop PC & 8 & $4.7 \%$ & 4 \\
Laptop PC & 143 & $84.6 \%$ & 1 \\
Tablet PC & 11 & $6.5 \%$ & 2 \\
Apple MacBook laptop & 6 & $3.6 \%$ & 3 \\
Netbook & 1 & $6.0 \%$ & 5 \\
\hline
\end{tabular}

The question on the preferred computer type also allowed for multiple responses. Table 3 shows that the preferred choices of computers for 169 respondents are desktops, laptops, tablets, the Apple MacBook and the Netbook. Most respondents prefer laptops for their computer access.

\section{Knowledge of computer use}

Less than $40 \%$ of the respondents use the resources of downloading and playing videos and audios on the computers that they regularly use, as shown in Table 6.

\section{TABLE 4}

\section{KNOWLEDGE OF COMPUTER USE}

\begin{tabular}{lccc} 
Reason & Frequency & \% & Rank \\
Yes, I can and I have & 99 & $37.4 \%$ & 1 \\
Yes, I can, but I have not & 63 & $23.8 \%$ & 3 \\
Yes, I can, but I struggle to do it & 28 & $10.6 \%$ & 4 \\
No, I can't & 75 & $28.3 \%$ & 2 \\
\hline & $\mathbf{2 6 5}$ & $\mathbf{1 0 0 . 1 \%}$ \\
\hline
\end{tabular}

About 190 respondents (71.8\%) could download and play videos and audios on their computers; $10.6 \%$ (28 respondents) struggled to download materials; and 28.3\% (about 75 respondents) were not able to download materials or play videos and audios on their computers. Thus, it can be concluded that close to $40 \%$ of the respondents need training in downloading materials and playing videos and audios on the computer.

\section{TABLE 5}

\section{REASONS FOR NOT HAVING INTERNET ACCESS}

\section{Location}

I cannot afford internet access packages on my budget

I do not own a personal computer from which I can access the internet

Internet coverage in the area I access a computer is inadequate (e.g. low strength)

I don't know how to arrange internet access for my computer

I cannot afford the travel costs to a facility with computers connected to the internet

The office hours of public facilities (Internet café or laboratory) I use are not convenient for me

I access someone else's computer and they do not have internet access

The public facility (Internet café or laboratory) I use does not have internet access

I am not allowed to access the internet on my work computer

I don't know anyone who has a computer with internet access

I have not needed internet access before

\begin{tabular}{ccc} 
Frequency & \multicolumn{1}{l}{$\%$} & Rank \\
45 & $55.6 \%$ & 1 \\
21 & $25.9 \%$ & 2 \\
8 & $9.9 \%$ & 3 \\
8 & $9.9 \%$ & 3 \\
& & \\
7 & $8.6 \%$ & 5 \\
& & \\
6 & $7.4 \%$ & 6 \\
6 & $7.4 \%$ & 6 \\
& & \\
3 & $3.7 \%$ & 8 \\
2 & $2.5 \%$ & 9 \\
2 & $2.5 \%$ & 9 \\
2 & $2.5 \%$ & 9 \\
\hline
\end{tabular}

Internet accessibility 
For access to a computer with internet, there were 298 responses. About $69.5 \%$ (207 respondents) have access to the internet. The 30.5\% (91 respondents) who do not have internet access gave the reasons for this (Table 5).

The main reason that was given for the lack of internet access was affordability. Some respondents (55.6\%, 45 respondents) indicated that they could not afford internet access packages on their budget. About a quarter of respondents $(25.9 \%)$ reported that they could not access the internet because they do not have a personal computer from which they can do so.

Figure 6 shows the distribution of distances travelled to access the internet. On average, the respondents travelled approximately $17 \mathrm{~km}$ to access the internet.

\section{FIGURE 6 \\ PERCENTAGE DISTRIBUTION OF DISTANCE TRAVELLED TO ACCESS INTERNET BY RESPONDENTS}

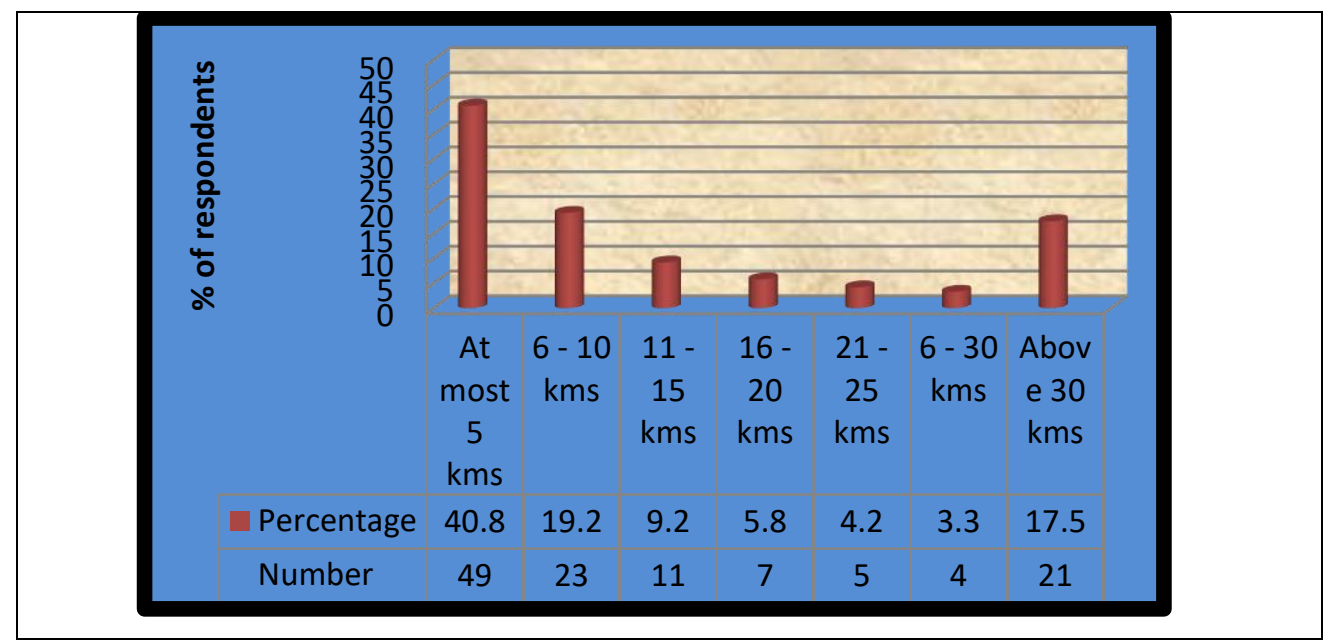

It is evident that some respondents travelled more than $30 \mathrm{~km}$ to access the internet. With reference to travel costs to obtain internet access, the respondents, on average spent R370.62 (approximately 26 US dollars) per month on travel costs to internet access locations. Figure 7 gives the monthly cost of travel to access the internet.

FIGURE 7

PERCENTAGE DISTRIBUTION OF MONTHLY COST OF TRAVEL TO ACCESS INTERNET BY RESPONDENTS

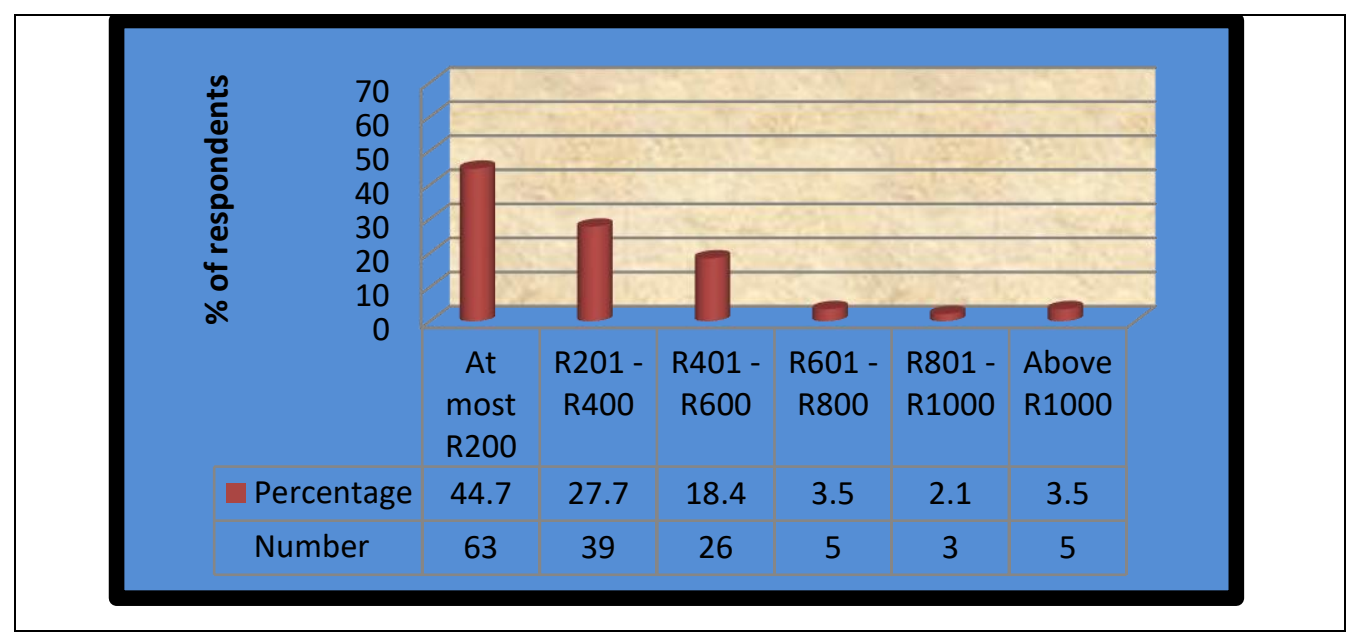

Table 6 shows the kind of internet access the respondents had on their computers. 
TABLE 6

\section{TYPE OF INTERNET ACCESS ON A COMPUTER}

\begin{tabular}{lccc} 
Type & Frequency & \% & Rank \\
Cell phone device with 3G/HSDPA & 72 & $29.1 \%$ & 1 \\
Don't know & 60 & $24.3 \%$ & 2 \\
3G/HSDPA modem (a modem is a high-speed mobile connection device) & 57 & $23.1 \%$ & 3 \\
ADSL (for example, from telecommunications service providers, such as & & & \\
Telkom and MWeb) & 54 & $21.9 \%$ & 3 \\
Company LAN (local area network) & 35 & $14.2 \%$ & 9 \\
\hline
\end{tabular}

Table 6 shows that there is no predominant type of internet access. There seems to be an equal usage of the different types of available internet access. The types of internet access used by the respondents are 3G/HSDPA, ADSL and LAN. Some respondents (24.3\%) could not tell which type of internet access they had.

\section{DISCUSSION OF THE FINDINGS}

This study found that the respondents had relatively high access to computers. This can be said to be a reflection of their ICT exposure in the course of their years of study at Unisa. In line with this assertion, Swart (2015) noted that poor e-skills are more common among first-year South African ODL students, and that mandatory ICT courses that are undertaken by senior students, such as the fourth-year students in this study, encourages the development of e-skills. Evidently, the use of laptops for educational purposes is making significant inroads in South African higher education institutions (Brown \& Pallitt, 2015). In South Africa the Universities of Cape Town (UCT) and Johannesburg (UJ) are at the forefront of laptop use to facilitate teaching and learning (Brown \& Pallitt, 2015). However, even though the supply of laptops to Unisa students is still in its infancy, the move is one that has been welcomed by the students as is evidenced by their comments on Facebook for Unisa students. It is expected that, in time, Unisa's provision of laptops to its eligible students (UNISA, 2019) will assist in improving Social Work students' use of computers to aid their practical modules and their studies in general.

The study also established that, ironically and paradoxically, access to computers does not necessarily translate into internet access. It was found that there was a $14 \%$ difference between the number of respondents who had access to computers only and those who had access to computers and the internet ( $83.5 \%$ and $69.5 \%$ respectively). Put differently, about one-third of the respondents $(30.7 \%)$ who had access to computers did not have access to the internet. The major reason given for this was lack of wherewithal. Similarly, Swart (2015) identified the exorbitant and unaffordable cost of internet connectivity as one of the challenges of ODL in South Africa. As a result of the time and money expended to commute to computer-access locations, some respondents indicated that they considered purchasing computers for the first time, or purchasing new computers. A significant number of the respondents, about $37.5 \%$, accessed computers for their studies away from their places of abode. These types of access required travelling over long distances. The long commute to locations where computers could be accessed and the associated financial costs attached to this was the reason why $14.7 \%$ did not make use of computers. Another reason why a large percentage of the respondents (77.1\%) did not use computers for academic purposes was because they could not afford to buy them.

Financial and geographical considerations and ICT skills and knowledge have an impact on ICT use by students in ODL institutions (Pena-Bandalaria, 2007). The results of this study indicate that some respondents do not use computers because they do not know how to use them. This is of great concern, given that technology, particularly computers and the associated technology, are central to open distance learning. Hurlbut (2018) explained the importance of technology in ODL when she asserted that the move from distance education to open distance learning necessitated the adoption of learning management systems and web resources compared to the use of print materials in times past. The lack of knowledge on how to use computers impacted negatively on some respondents' study activities, since about one third of them could not play videos and audios on their computers or download materials. However, these activities are particularly important for the students in 
recording and uploading their case and group work. Hence, it is recommended that Social Work students undergo compulsory computer literacy classes starting from their first year of study, as well as refresher courses on computer use through each year of their studies until graduation.

\section{IMPLICATIONS AND RECOMMENDATIONS}

The findings of this study indicate the extent to which students have access to the computer and internet, and their ability to use computer software to upload or download video and audio material for assessment of their practical work. An ideal situation would be for all students to have access to computers and the internet, and to be able to upload and download materials for their practical work. This would minimise travelling costs, since the students would be able to capture a video or audio of their practical work in the presence of their supervisor and send it to the lecturer for assessment. Bozalek and Ng'ambi (2015) 4. maintain that, although more students in South Africa have access to digital devices, some students come to university with insufficient access to ICTs and without basic computer skills. The authors further stated that "in South Africa, the insufficient access to ICTs is a general challenge that is rooted in the fact that only a few homes have computers and internet access" The result is that these students come into contact with computers for the first time at university.

The portfolios of evidence should ideally be captured electronically and submitted for assessment, which will turn them into e-portfolios. Pallitt, Strydom and Ivala (2015:32) define an e-portfolio as a "purposeful collection of information and digital artefacts that demonstrates development of evidences learning outcomes, skills or competencies" which serves the purposes of tracking "student development and connections over time ... and to instil values of lifelong, self-directed learning and professional development". A compilation and submission of e-portfolios requires the use of technology, specifically computers and the internet. The authors went on to argue that e-portfolios are used locally and internationally in professional degrees like education, engineering, health sciences and architecture (2015). This is because these professions have professional bodies and quality assurance standards. Social Work is a professional degree in South Africa, regulated by the Council for Higher Education and the South African Council for Social Service Professions (Social service Professions Act, 110 of 1978). If Social Work students submit e-portfolios, these bodies would be in a position to set quality assurance standards.

The findings of this study also offer insights into the implications of the lack of access to technology, computers and the internet. It was shown that this constitutes an obstacle to conducting the practical assessments online or by other electronic means, as should be the case in an ODL institution. In the absence of access to technology, computers and the internet, the only alternative is for the assessments to be done face-to-face. This, in turn, has implications for the allocation and management of resources. It is recommended that the university provide students doing practical work with computers and internet access to facilitate the move towards becoming a fully ODL institution. The partnerships that the university has with telecentres in the regions should be widely advertised so that all students become aware of them.

\section{CONCLUSION}

This study investigated technology use within an ODL institution and its implication for assessment of the Social Work practical module. The aim of this study was to explore and describe the use of technology for assessing the group work practicals of final-year students in Social Work at Unisa. This has been done by assessing the extent to which the students have access to computers and the internet, and their ability to use these to upload/download video or audio materials. The ability to carry out these activities can minimise travel and time costs for students to capture videos or audios of their practical work and send the work to the lecturer for assessment. Ideally, the students' portfolios can also be captured electronically and submitted for assessment. It was noted that some students have access to computers, but not necessarily connectivity to the internet. Others do have access to computers or the internet. Access to computers and the internet comes with financial and time costs for students because of the distances travelled and money spent in doing so. This, therefore, makes it difficult to do assessments by means other than face-to-face interviews. And this, in turn, has implications for resource allocation and management. 


\section{REFERENCES}

AHMED, S.M. \& PALERMO, A.S. 2010. Community engagements in Research: Frameworks for education and Peer Review. American Journal of Public Health, 100(8):1380 -1387.

ARINTO, P. 2016. Issues and challenges in open and distance e-learning: Perspectives from the Philippines. International Review of Research in Open and Distributed Learning, 17(2):162-180.

BOZALEK, V. \& NG'AMBI D. 2015. The context of learning with technology. In: KILFOIL, W.R. (ed). Moving beyond the hype: A contextualised view of learning with technology in higher education. Pretoria: Universities South Africa.

BROWN, C. \& PALLITT, N. 2015. Personal mobile devices and laptops as learning tools. In: KILFOIL, W.R. (ed). Moving beyond the hype: A contextualised view of learning with technology in higher education. Pretoria: Universities South Africa.

CHAWINGA, W.D. \& ZOZIE, P.A. 2016. Increasing access to higher education through Open and Distance Learning: Empirical findings from Mzuzu University, Malawi. International Review of Research in Open and Distributed Learning, 17(4):1-20.

COMMONWEALTH OF LEARNING. [Sa] International partnership of distance and online learning for COVID-19. [Online] Available: https://opendoor.col.org/ [Accessed: 08/07/2020].

COULBY, C., HENNESSEY, S., DAVIES, N. \& FULLER C. 2011. The use of mobile technology for work based assessment: the student experience. British Journal of Educational Technology, 42(2):251265.

COUNCIL ON HIGHER EDUCATION. 2014. Distance higher education programmes in a digital era: Good practice guide. Pretoria: Council on Higher Education.

COURTNEY, M. \& WILHOITE-MATHEWS, S. 2015. From distance education to online learning: Practical approaches to information literacy instruction and collaborative learning in online environments. Journal of Library Administration, 55(4):261-277.

CRESWELL, J.W. 2009. Research design: Qualitative, quantitative, and mixed methods approaches. California: Sage.

DELPORT, C.S.L. \& ROESTENBURG, W.J.H. 2011. Quantitative data collection methods: indexes and scales. In: DE VOS, A.S., STRYDOM, H., FOUCHE, C.B. \& DELPORT, C.S.L (ed). Research at grass roots for the social sciences and human service professions. Pretoria: Van Schaik.

DINISMAN, T. 2016. Life satisfaction in the transition from care to adulthood: The contribution of readiness to leave care and social support. Child and Family Social Work, 21:401-411.

ETIKAN, I. \& BALA, K. (2017). Sampling and sapling methods. Biometrics and Biostatistics International Journal, 5(6): 1-3.

ETIKAN, I., MUSA, S.A. \& ALKASSIM, R.S. 2016. Comparison of convenience sampling and purposive sampling. American Journal of Theoretical and Applied Statistics, 5(1):1-4.

FRANKFORT-NACHMIAS, C. \& NACHMIAS, D. 2000. Research in social sciences. $\left(6^{\text {th }}\right.$ ed). New York: Worth.

GEORGE, D. \& MALLERY, P. 2003. SPSS for Windows step by step: A simple guide and reference. ( $4^{\text {th }}$ ed). Boston: Ally \& Bacon.

GERRING, J. 2012. Social science methodology: A unified framework (Strategies for social inquiry). $\left(2^{\text {nd }}\right.$ ed). New York: Cambridge.

GLEASON, N.W. 2018. Singapore's higher education systems in the era of the fourth industrial revolution: Preparing lifelong learners. In: GLEASON, N.W. (ed). Higher education in the era of the fourth industrial revolution. Singapore: Palgrave Macmillan. 
GILLWALD, A. (ed). 2017. Internet use barriers and user strategies: Perspectives from Kenya, Nigeria, South Africa and Rwanda. [Online] Available: https://www.researchictafrica.net/docs/RIA\%202016\%20Comparative\%20FGD\%20study_Final_Web\%20version.pdf [Accessed: 22/06/2020].

HMC ARCHITECTS. [Sa]. Distance learning in the time of COVID-19. [Online] Available: https://hmcarchitects.com/news/distance-learning-in-the-time-of-covid-19/ [Accessed: 08/07/2020].

HURLBUT, A.R. 2018. Online vs. traditional learning in teacher education: A comparison of student progress. American Journal of Distance Education, 32(4):248-266.

IQBAL, M. J. \& AHMAD, M. 2010. Enhancing quality of education through e-learning: The case study of Allama Iqbal Open University. Turkish Online Journal of Distance Education, 11(1):84-97.

JEONG, M.S. 2018. New mission for new time in Korean higher education. Journal of Comparative and International Higher Education, 10:32-38.

JONASSEN, D.H. 1991. Evaluating constructivist learning. Educational Technology, 28(11):13-16.

KASHORA, T., VAN DER POLL, H.M. \& VAN DER POLL, J.A. 2012. E-learning technologies for open distance learning knowledge acquisition in management accounting. Proceedings of Informing Science and IT Education Conference. [SI]. [Online] Available: http://proceedings.informingscience.org/InSITE2012/InSITE12p189-203Kashora0056.pdf [Accessed: 22/06/2020].

KROSNIK, J.A. 2018. Questionnaire design. In: VANNETTE, D. \& KROSNICK, J. (eds). The Palgrave Handbook of Survey Research. London: Palgrave Macmillan.

LANDRENEAU, K.J. n.d. "Sampling strategies" [Online] Available: http://www.natco1.org/research/files/samplingstrategies.pdf [Accessed: 22/06/2020].

LEE, K. 2017. Rethinking the accessibility of online higher education. Internet and Higher Education, $33: 15-23$.

LETSEKA, M. \& PITSOE, V. 2013. Reflections on assessment in Open Distance Learning (ODL): The case of the University of South Africa (UNISA). Open Praxis, 5(3):197-206.

LIU, C.C \& CHEN, I.J. 2010. Evolution of constructivism. Contemporary Issues in Educational Research, 3(4):63-66.

MADIOPE, M. \& GOVENDER D. 2015. Distance education and supporting technologies for open and distance learning. In: KILFOIL, W.R. (ed). Moving beyond the hype: A contextualised view of learning with technology in higher education. Pretoria: Universities South Africa.

MOHAPI, B.J. 2010. Only study guide for SCK4804. Pretoria: University of South Africa.

NEUMANN, W. L. 2000. Social Research Methods: Qualitative and quantitative methods. Boston: Allyn and Bacon.

OLUSEGUN, B.A. 2015. Constructivism learning theory: A paradigm for teaching and learning. IOSR Journal of Research and Method in Education, 5(6):66-70.

PADIRAYON, L.M., PAGUDPUD, M.V. \& CRUZ, J.S.D. 2019. Exploring constructivism learning theory using mobile game. IOP Conference Series: Materials Science and Engineering. [Online] Available: https://iopscience.iop.org/article/10.1088/1757-899X/482/1/012004/pdf $\quad$ [Accessed: 22/06/2020].

PALLITT, N., STRYDOM S. \& IVALA. E. 2015. E-portfolios. In: KILFOIL, W.R. (ed). Moving beyond the hype: A contextualised view of learning with technology in higher education. Pretoria: Universities South Africa.

PENA-BANDALARIA, M.D. 2007. Impact of ICTs on Open and Distance Learning in a developing country setting: The Philippine experience. International Review of Research in Open and Distance Learning, 8(1):1-15. 
PENPRASE, B.E. 2018. The fourth industrial revolution and higher education. In: GLEASON, N.W. (ed). Higher education in the era of the fourth industrial revolution. Singapore: Palgrave Macmillan. QIU, J. 2019. A preliminary study of English mobile learning model based on constructivism. Theory and Practice in Language Studies, 9(9):1167-1172.

REIO, T.G. 2016. Nonexperimental research design: Strengths, weaknesses and issues of precision. European Journal of Training and Development, 40(8/9):676-690.

ROGERSON-REVELL, P. 2015. Constructively aligning technologies with learning and assessment in a distance education master's programme. Distance Education, 36(1):129-147.

SAKARNEH, M.A. \& AL-SWELMYEEN, M.B. 2020. The extent to which the Jordanian inclusive basic school teachers use the constructivism theory in teaching. Journal of Educational and Social Research, 10(1):182-197.

SULLIVAN, L. (ed). 2009. The Sage Glossary of the Social and Behavioral Science. California: Sage. SWART, A.J. 2015. Student usage of a learning management system at an open distance learning institute: A case study in electrical engineering. International Journal of Electrical Engineering Education, 52(2):142-154.

TAI, M.C. 2012. Deception and informed consent in social, behavioral, and educational research (SBER). Tzu Chi Medical Journal, 24:218-222.

TAYLOR, J.D., DEARNLEY, C.A., LAXTON, J.C., COATES, C.A., TREASURE-JONES, R., CAMPBELL, R. \& HALL, I. 2010. Developing a mobile learning solution for health and social care practice. Distance Education, 31(2):175-192.

THE LEADING ODL TAYLOR. 2019. [Online] Available: https://www.unisa.ac.za/sites/corporate/default/About/The-leading-ODL-university [Accessed: 02/03/2020].

UNISA. 2008. Open Distance Learning Policy. Pretoria.

UNISA. 2019. Major ICT boost for Unisa students as first laptops are issued. [Online] Available: https://www.unisa.ac.za/sites/myunisa/default/News/Articles/Major-ICT-boost-for-Unisa-students-asfirst-laptops-are-issued [Accessed: 22/06/2020).

UNISA. [Sa]a. myUNISA. [Online] Available: https://www.unisa.ac.za/sites/myunisa/default/ [Accessed: 01/04/2020].

UNISA. [Sa]b. Regional centres. [Online] Available: https://www.unisa.ac.za/sites/corporate/default/Contact-us/Regional-Centres [Accessed: 01/04/2020].

UNISA. [Sa]c. Facts \& figures. [Online] Available: https://www.unisa.ac.za/sites/corporate/default/About/Facts-\&-figures [Accessed: 22/06/2020].

XING, B. \& MARWALA, T. 2017. Implications of the fourth industrial age for higher education. Science and Technology, 73:10-15. 